\title{
Sprawozdanie
}

\section{Seminarium Młodych Badaczy Prawa Konstytucyjnego nt.: Deficyt demokracji czy legitymacji - monarchie i republiki w Europie, Kazimierz Dolny, 13-15 września 2011 r.}

Seminarium Młodych Badaczy Prawa Konstytucyjnego zostało zorganizowane w dniach 13-15 września w Kazimierzu Dolnym nad Wisłą już po raz czwarty. Tym razem doszło ono do skutku w dużej mierze dzięki uprzejmości i wysiłkowi organizacyjnemu przedstawicieli łódzkiego ośrodka akademickiego. IV Seminarium, będące w swej istocie konferencją naukową, jest kontynuacją znakomitej inicjatywy podjętej po raz pierwszy w Mąchocicach Kapitulnych w marcu 2010 r. przez prawników i politologów specjalizujących się w szeroko rozumianej problematyce prawa państwowego. Cykliczne spotkania służą realizacji wielu istotnych z punktu widzenia młodego polskiego środowiska uniwersyteckiego, celów. Są swoistą platformą do swobodnej wymiany myśli, zaprezentowania różnorodnych poglądów naukowych, skonfrontowania tez badawczych, omówienia głównych nurtów zmian prawa konstytucyjnego zarówno w Polsce, jak i na świecie. Pozwalają na konsolidację środowiska młodych akademików, a w konsekwencji skutkują opracowanymi publikacjami, jak chociażby „Przegląd Prawa Konstytucyjnego” oraz wspólnie realizowanymi projektami.

Tematem przewodnim IV Seminarium było zagadnienie deficytu demokracji oraz legitymacji na przykładzie monarchii i republik europejskich. Należy wspomnieć, że w jednym z referatów (mowa o referacie dr. Artura Ławniczaka z Uniwersytetu Wrocławskiego) zakres problematyki został rozszerzony o niektóre państwa kontynentu afrykańskiego.

Dzień obrad wyznaczony został na 14 września. Prezentacje referatów odbywała się w dwóch sesjach: pierwszej - porannej, zatytułowanej Realizacja demokratycznej formy rzadów w wybranych państwach europejskich oraz drugiej - popołudniowej, nazwanej Argument demokracji w uzasadnieniu sprawowanej władzy. Uroczystego przywitania gości oraz otwarcia IV Seminarium dokonała jedna z głównych organizatorek imprezy, a zarazem prze- 
wodnicząca pierwszej sesji obrad, dr hab. Anna Młynarska-Sobaczewska z Uniwersytetu Łódzkiego. W sesji porannej zaprezentowane zostały dwa z trzech przewidzianych referatów. Prelegentkami były dr Marta Kłopocka-Jasińska z Wyższej Szkoły Menedżerskiej w Legnicy oraz dr Anna Michalak z Uniwersytetu Łódzkiego.

Dr Marta Kłopocka-Jasińska wygłosiła referat nt. króla jako głowy państwa w świetle Konstytucji Królestwa Hiszpanii z 1978 r. Mówczyni w swoim wystąpieniu omówiła kilka ważkich zagadnień. Na początku odniosła się do restauracji monarchii „katolickiej, socjalnej i tradycyjnej” w Hiszpanii w 1947 r. za autorytarnych rządów generała Francisco Franco. Następnie wskazała na proces demokratyzacji państwa po objęciu tronu przez Don Juana Carlosa I de Borbon w 1975 r., a także podkreśliła doniosłą rolę procesu uchwalania i przyjęcia w referendum hiszpańskiej Konstytucji z 1978 r., która do dziś gwarantuje dziedziczność korony, brak odpowiedzialności króla, oraz powierzenie wykonywania władzy ustawodawczej Kortezom Generalnym. Kończąc swe wystąpienie, dr M. Kłopocka-Jasińska poddała analizie procedurę sukcesji hiszpańskiego tronu oraz wskazała na rolę, jaką aktualnie odgrywa głowa państwa w monarchii parlamentarnej w Królestwie Hiszpanii. Wyszczególniła, iż uznaje się króla za symbol jedności i trwałości państwa, sam król zaś pełni funkcję mediatora, moderatora oraz arbitra.

Wygłoszony przez dr M. Kłopocką-Jasińską stał się przyczynkiem do ożywionej dyskusji, w której próbowano odnieść się do tak problematycznych pytań jak: czy w obrębie rodziny królewskiej dzieci spoza małżeństwa oraz dzieci adoptowane mogą liczyć na równy dostęp do tronu hiszpańskiego, powołując się na art. 39 Konstytucji mówiący o równości dzieci wobec prawa niezależnie od ich pochodzenia, a także na konstytucyjną gwarancję prawa do obejmowania na równych zasadach funkcji i urzędów publicznych. Zwrócono uwagę, iż nie jest jednoznaczne, czy urząd króla można zaliczyć do kategorii urzędów publicznych. Na koniec gorącej debaty dr Marcin Wiszowaty poruszył problem małżeństw morganatycznych i wątpliwości towarzyszących kwestii możliwości zastosowania zasad dziedziczenia z zakresu prawa cywilnego do zagadnienia dziedziczenia tronu.

Drugi w kolejności wygłoszonym został referat dr Anny Michalak (Uniwersytet Łódzki), zatytułowany Legitymacja rządów koalicyjnych w systemie konstytucyjnym Wielkiej Brytanii. Prelegentka w swoim wystąpieniu wskazała, iż Wielka Brytania nie posiada pisanej konstytucji, tj. jednego aktu regu- 
lującego ustrój polityczny państwa rozumianego jako źródło prawa w ujęciu formalnym. Zastosowanie na gruncie prawa konstytucyjnego, jak zaznaczyła dr A. Michalak, za to z powodzeniem znajdują konwenanse i precedensy konstytucyjne. Mówczyni uwydatniła dwie istotne prerogatywy monarchy brytyjskiego, mające wpływ na proces tworzenia gabinetu w Wielkiej Brytanii. Jako pierwszą wskazała mianowanie na premiera, zgodnie z konwenansem konstytucyjnym, przywódcy partii większościowej w Izbie Gmin, a jako drugą prawo rozwiązania parlamentu. W trakcie dyskusji na referatem stanęło pytanie o źródło legitymacji rządów koalicyjnych w Wielkiej Brytanii. Dr A. Michalak zaznaczyła, że w przypadku „Zawieszonego parlamentu” władzę legitymuje były premier, gdyż to do niego należy faktycznie pierwszy ruch. Natomiast adwersarz w sporze, dr K. Urbaniak, wskazał, że to monarcha powołuje premiera, $\mathrm{i}$ owo powołanie $\mathrm{w}$ istocie legitymuje premiera do wykonywania powierzonej mu funkcji.

Ostatni z referatów przewidziany na czas sesji porannej nie został wygłoszony. Jednakże jego autor, mgr Marcin Przybysz (Uniwersytet Szczeciński), przesłał na ręce organizatorów opracowanie poświęcone zasadzie republikańskiej formy rządów w RFN, z którego treścią będzie można zapoznać się na łamach kwartalnika „Przegląd Prawa Konstytucyjnego”.

W przerwie obrad uczestnicy Seminarium udali się na krótki spacer chłonąc piękno kazimierzowskich ulic oraz doceniając urokliwe, jesienne, nadwiślańskie pejzaże.

Sesji popołudniowej, zatytułowanej Argument demokracji w uzasadnieniu sprawowania władzy, przewodniczył dr Krzysztof Urbaniak (Uniwersytet im. Adama Mickiewicza w Poznaniu).

Należy wspomnieć, iż podczas drugiej części obrad swoją obecnością zaszczycił dyskutujących znakomity nestor rodu polskich konstytucjonalistów, prof. dr hab. Wiesław Skrzydło.

Pojawienie się Profesora wywołało na sali burzę oklasków. Uczestnicy mogli cieszyć się z towarzystwa znamienitego gościa także podczas uroczystej kolacji, za co pragną złożyć mu serdeczne podziękowania!

Pierwszy referat inaugurujący sesję popołudniową wygłosił dr Ryszard Balicki (Uniwersytet Wrocławski), który w swoim wystąpieniu odniósł się do problemu deficytu demokracji w Unii Europejskiej. Mówca rozpoczął swą wypowiedź od postawienia kilku istotnych pytań: pierwsze z nich brzmiało: czy można mówić o demokracji na poziomie organizacji międzynarodowej?, 
drugie: czy organizacja międzynarodowa może spełniać kryteria pozwalające uważać ją za demokratyczną? oraz trzecie: czy można w prosty sposób przenieść pewne pojęcia zastane i wykorzystywane w opisie funkcjonowania państw - na poziom organizacji międzynarodowych? Kontynuując rozważania, dr R. Balicki omówił pojęcie „deficytu” oraz źródeł demokracji odnosząc się do starożytnych polis greckich. Wspomniał, iż na poziomie europejskim przyczynkiem do dyskusji nad deficytem demokracji w UE stał się tzw. raport Vedela z 1972 r. W ostatniej części swego wystąpienia referent podjął próbę sprecyzowania, czym Unia Europejska jest, a czym nie jest oraz zaakcentował, że demokracja jest stale dziejącym się procesem, o właściwy kierunek którego wszyscy obywatele UE powinni stale zabiegać.

Referat wywołał burzliwą dyskusję, w której najaktywniej uczestniczyli: dr Radosław Grabowski (Uniwersytet Rzeszowski), dr Krzysztof Urbaniak, dr Olga Łachacz (Uniwersytet Warmińsko-Mazurski), dr Piotr Uziębło (Uniwersytet Gdański). Dr O. Łachacz postawiła tezę, że z punktu widzenia prawa międzynarodowego publicznego Unia Europejska po Traktacie z Lizbony $\mathrm{w}$ sensie prawnym jest organizacją międzynarodową o charakterze ponadnarodowym. Dr K. Urbaniak zadał zaś interesujące pytanie o to, w czym upatrywać deficytu demokracji unijnej i na ile można określić europejski demos. Dr P. Uziębło zwrócił dodatkowo uwagę na problem fasadowości parlamentów krajowych oraz na fakt, iż organy unijne, w których zapadają decyzje wiążące członków UE, nie mają bezpośredniej legitymizacji, co w konsekwencji wyklucza możliwość mówienia o demokracji UE.

Dr Marcin Wiszowaty (Uniwersytet Gdański) jako drugi w sesji popołudniowej zaprezentował referat nt. legitymizacji rządów monarchicznych w drodze referendum. Na początku swego wystąpienia referent zwrócił uwagę na odmienne obiekty legitymizacyjne w odniesieniu do rządów republikańskich (tutaj rządy oparte są na zasadach elekcyjności i kadencyjności) i rządów monarchicznych (tutaj zaś, gdzie władza królewska ma charakter dziedziczny i jest sprawowana dożywotnio, główną rolę odgrywają argumenty idealistyczne, np. uzasadnienie, iż władza monarsza pochodzi od Boga). Następnie prelegent wskazał na dwóch myślicieli, których idee wywarły ogromy wpływ na rozumienie pojęcia legitymizacji, tj. Francisa Bacona oraz św. Tomasza z Akwinu. Istotną część wystąpienia dr. M. Wiszowatego stanowiło omówienie tych przypadków, w których po 1944 r. monarchie sięgnęły do instytucji referendum, zdając się na niniejszą procedurę w kwe- 
stii rozstrzygnięcia o ustroju państwa (od końca II wojny światowej odbyły się 22 referenda, które dotyczyły monarchii). W swej wypowiedzi mówca zaakcentował fakt, iż wielokrotnie uznawano referendum za najodpowiedniejszy, bo najpełniej legitymizujący, sposób decydowania o wyborze formy ustrojowej państwa. Konkludując, dr M. Wiszowaty zauważył, iż z jednej strony organizowanie referendów w monarchiach konstytucyjnych może wskazywać na zanik owej formy rządów, z drugiej natomiast - jego zdaniem - trudno wykluczyć sytuację, w której kiedyś, właśnie w drodze referendum, nastąpi proces restytucji monarchii w państwach republikańskich.

Część popołudniową obrad zakończyło barwne i pełne ekspresji wystąpienie dr. Artura Ławniczaka (Uniwersytet Wrocławski), w którym prelegent przedstawił referat zatytułowany Afrykański model monarchii jako wyzwanie. $\mathrm{W}$ swoim wystąpieniu mówca zaprezentował modele ustrojowe charakterystyczne dla kontynentu afrykańskiego, wskazując m.in. na rdzennoplemienne demokracje (przykładem może być Ghana) oraz model marokański (do połowy XX w. sułtanat, dziś monarchia konstytucyjna, w której król posiada status duchowego przywódcy wszystkich Marokańczyków). Dr A. Ławniczak zwrócił także uwagę na pewną prawidłowość, mianowicie w większości krajów afrykańskich prezydenci wybierani są dożywotnio.

Uwieńczeniem pracowitego dnia obrad była uroczysta kolacja, na której zgromadzili się i odpoczywali w wyśmienitej atmosferze wszyscy uczestnicy Seminarium. Szczególne podziękowania za znakomitą organizację kolejnego cyklu imprezy należą się przede wszystkim Pani dr hab. Annie Młynarskiej-Sobaczewskiej. Wysoki poziom merytoryczny referatów, możliwość zaprezentowania przez uczestników różnorodnych sądów, sposobność swobodnej wymiany poglądów oraz klimat sprzyjający odważnemu dyskursowi naukowemu wydają się na trwałe wpisywać w charakter spotkań młodych badaczy prawa konstytucyjnego.

Joanna Uliasz (Uniwersytet Rzeszowski) 